\title{
Interaction between Mesodinium rubrum and its prey: importance of prey concentration, irradiance and $\mathrm{pH}$
}

\author{
Morten Smith, Per Juel Hansen* \\ Marine Biological Laboratory, University of Copenhagen, Strandpromenaden 5, 3000 Helsingør, Denmark
}

\begin{abstract}
The functional and numerical responses for the marine obligate mixotrophic ciliate Mesodinium rubrum Lohmann, 1908 (=Myrionecta rubra Jankowsky, 1976) were studied at 2 irradiances

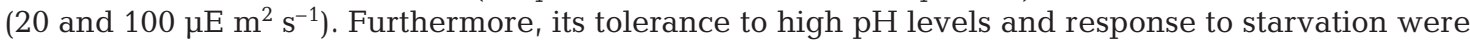
studied in mixed cultures of $M$. rubrum and Teleaulax sp. The functional and numerical response study showed that the threshold concentration of the cryptophyte Teleaulax sp. was 50 cells ml $^{-1}$ and the maximum growth of M. rubrum was 0.23 and $0.49 \mathrm{~d}^{-1}$ for 20 and $100 \mu E \mathrm{~m}^{2} \mathrm{~s}^{-1}$, respectively. Calculation of ingestion rates revealed that $\sim 1$ Teleaulax sp. cell M. rubrum ${ }^{-1} \mathrm{~d}^{-1}$ was sufficient to maintain the maximum growth rate. Maximum ingestion rates were independent of light and saturated at $\sim 6$ Teleaulax sp. cells $M$. rubrum ${ }^{-1} \mathrm{~d}^{-1}$. A heterotrophic carbon uptake of from 2 to $4 \%$ of $M$. rubrum carbon content was sufficient for maximum growth, but carbon contributions as high as $22 \%$ were observed to have no effect on growth. The pH experiments revealed that the growth of M. rubrum and Teleaulax sp. was impeded at pH levels in excess of 8.5 and 8.8, respectively. Experiments to reveal $M$. rubrum's response to starvation showed that $M$. rubrum could survive for around $50 \mathrm{~d}$ without prey. These results are all discussed with respect to $M$. rubrum's adaptation to its environment.
\end{abstract}

KEY WORDS: Mesodinium rubrum $\cdot$ Myrionecta rubra $\cdot$ Functional numerical response $\cdot$ Irradiance Starvation $\cdot \mathrm{pH}$ Resale or republication not permitted without written consent of the publisher

\section{INTRODUCTION}

Mesodinium rubrum Lohmann, 1908 (=Myrionecta rubra Jankowsky, 1976) is a common photosynthetic ciliate in coastal ecosystems (archipelagos, bays, inlets, fjords, etc.) all over the world (Lindholm 1985). It is particularly well known for its reddish brown blooms, which, in many areas, are a recurrent phenomenon. This phenomenon was first described by Charles Darwin off the coast of Chile in 1840, and, since then, there have been many such reports from all over the world (cf. Lindholm 1985). The photosynthesis of M. rubrum may, in many cases, be substantial compared to traditional phytoplankton groups and, in some cases, be responsible for up to $70 \%$ of the community photosynthesis (Stoecker et al. 1991).

The nature of the numerous reddish brown chloroplasts of Mesodinium rubrum has been a matter of some controversy. It became clear from the studies by
Hibberd (1977) that the chloroplasts of M. rubrum are derived from cryptophytes. Hibberd (1977) also discovered that the numerous ( 20) chloroplasts were delimited from the ciliate cytoplasm by a single membrane and that a single symbiont nucleus was also presentan organisation unlike any known cryptophyte. Because no signs of a cytostome were found in $M$. rubrum, it was assumed to contain an endosymbiont, making $M$. rubrum entirely phototrophic (Hibberd 1977, Oakley \& Taylor 1978).

Numerous attempts to culture Mesodinium rubrum had failed before Gustafson et al. (2000) succeeded in culturing an Antarctic clone of $M$. rubrum by offering it the red cryptophyte Teleaulax acuta as prey. Thus, it became evident that $M$. rubrum actually had a mouth of some sort. In an earlier work, Kudo (1954) actually drew M. rubrum (syn. Cycloterium meunieri Powers, 1931) with a distinct cytostome, and Lohmann (1908) also mentioned a 'mouth' in his work. The actual feeding process 
in $M$. rubrum was, however, not documented until very recently (Yih et al. 2004). This process involves the bifurcate anterior tentacles (Lindholm 1985) acting as harpoons as the cell reacts to the hydromechanical signal delivered by the motile prey, as has been described for Mesodinium pulex (Jakobsen et al. 2006).

A new hypothesis on the functional biology of Mesodinium rubrum was put forward by Gustafson et al. (2000) and Johnson \& Stoecker (2005). They proposed that $M$. rubrum stole the chloroplasts from its prey (kleptoplastidy), which is a common phenomenon for ciliates (Stoecker et al. 1987). Thus they dismissed the previous conception of this ciliate harbouring a permanent symbiont. Their conclusions were based on the disappearance of prey nuclei while chlorophyll $a$ was retained. Hansen \& Fenchel (2006) rejected the kleptoplastidy hypothesis, because they found no substantial decline in chloroplast number as the ciliate proliferated for prolonged periods in unfed cultures, and thus supported earlier claims that $M$. rubrum contains an endosymbiont. Further, the study by Hansen \& Fenchel (2006) states that growth of $M$. rubrum is affected at a pH of 8.55 . Thus, any functional or numerical experiments with ciliates carried out in the light must take $\mathrm{pH}$ into account.

The interaction between Mesodinium rubrum and its cryptophyte prey (Teleaulax sp.) has previously been studied, under the assumption of kleptoplastidy, as a means of boosting the growth of $M$. rubrum (Yih et al. 2004). With the (re)discoveries of Hansen \& Fenchel (2006) in mind, the aim of the present work was to present a functional and numerical response of this obligate mixotrophic ciliate at 2 irradiances. Furthermore, tolerance of high $\mathrm{pH}$ and starvation responses are presented and included in a discussion of the ecological adaptation of $M$. rubrum. The evidence is based on simple feeding experiments from which growth and ingestion rates are calculated.

\section{MATERIALS AND METHODS}

Cultures. A culture of Mesodinium rubrum Lohmann, 1908 was established using water from Ellsinore Harbour. Cells were isolated from a sample of natural seawater with a drawn Pasteur pipette and transferred to a multi-dish well ( 24 wells). Then, $2 \mathrm{ml}$ of a dilute Teleaulax sp. culture was added to each of the wells containing the M. rubrum cells. The Teleaulax sp. was isolated from the northern part of the sound (Denmark) and provided by the culture collection at the Marine Biological Laboratory of the University of Copenhagen. All cultures were kept in seawater-based $f / 2$ medium (Guillard 1983) of approximately 30 psu on a glass table. This medium ensured that the cultures were never nutrient limited (see Hansen 2002). Light (cool white, $100 \mu \mathrm{E} \mathrm{m}^{-2} \mathrm{~s}^{-1}$ ) was provided from beneath the table following a $16 \mathrm{~h}$ light: $8 \mathrm{~h}$ dark photocycle. All experiments were performed at a temperature of $15 \pm$ $1^{\circ} \mathrm{C}$.

Growth and pH dynamics. Seawater of 30 psu has a high buffer capacity due to its high concentration of inorganic carbon. However, in coastal areas, the amount of inorganic carbon taken up by phototrophs will lead to elevated pH (e.g. Macedo et al. 2001, Hansen 2002). Preliminary experiments on this isolate had shown that the growth of Mesodinium rubrum might be affected when $\mathrm{pH}$ exceeded 8.5, similar to the results reported by Hansen \& Fenchel (2006). Thus, an experiment was initiated in which $M$. rubrum and Teleaulax sp. were mixed in concentrations of 250 and 2000 cells $\mathrm{ml}^{-1}$, respectively, and allowed to grow. A monoculture of Teleaulax sp. was also initiated to establish the upper $\mathrm{pH}$ limits of the cryptophyte alone. These experiments were all carried out in $65 \mathrm{ml}$ tissueculture bottles filled to capacity. Samples $(2 \mathrm{ml})$ were withdrawn 3 times a week; $\mathrm{pH}$ was measured directly in the bottles, and the bottles were subsequently refilled to capacity with fresh $f / 2$ medium ( $\mathrm{pH} 7.9$ ). When $\mathrm{pH}$ reached 8.5 in the mixed culture, the culture was diluted 10 times and allowed to grow further. In this way it was possible to separate $\mathrm{pH}$ effects from starvation effects (see following subsection). To measure $\mathrm{pH}$ a Sentron Isfet $\mathrm{pH}$-meter was used with either a Red line or Argus X probe, which was calibrated using standard buffers of $\mathrm{pH} 7$ and 10.

Starvation response. The growth and $\mathrm{pH}$ dynamics experiment clearly showed that the starvation response was a key element in understanding the growth dynamics of Mesodinium rubrum. Experiments were therefore set up to follow the growth of $M$. rubrum for 30 to $60 \mathrm{~d}$ in 3 different situations. Cultures grown under photon flux densities of 20 and $100 \mu \mathrm{E}$ $\mathrm{m}^{-2} \mathrm{~s}^{-1}$ (LL: low light and HL: high light, respectively) were acclimated to low prey concentrations $(<100$ cells $\mathrm{ml}^{-1}$ ), and $1 \mathrm{HL}$ culture was offered a high concentration of prey $\left(\sim 2000\right.$ cells ml$\left.^{-1}\right)$ (same culture method described in the previous subsection). Initial concentrations of $M$. rubrum were $\sim 250$ in all cultures. Then, $2 \mathrm{ml}$ samples were taken at intervals of 2 to $5 \mathrm{~d}$. The experiments were conducted within the $\mathrm{pH}$ constraints found in the growth experiments above.

Functional and numerical response. Growth experiments as a function of the average prey concentration were carried out at 2 irradiances: LL and HL, with photon flux densities of 20 and $100 \mu \mathrm{E} \mathrm{m}^{-2} \mathrm{~s}^{-1}$, respectively. Irradiance was measured using a Li-1000, Li-Cor sensor equipped with a spherical probe. Triplicates of a mixed Mesodinium rubrum and Teleaulax sp. culture and a control culture consisting of only Teleaulax sp. were set up in $65 \mathrm{ml}$ tissue-culture bottles and accli- 
mated to the respective irradiances. Initial prey concentrations ranged from 100 to 10000 cells ml$^{-1}$. The mixed culture was acclimated to the given average prey concentration of a $5 \mathrm{~d}$ experimental period before starting the actual experiments. Samples were withdrawn at Days 0, 2 and 4 and fixed in Lugol's (final concentration of $2 \%$ ). Cells were enumerated in a Sedgewick-Rafter chamber using an inverted microscope, and a minimum of 100 cells was counted. Samples that contained $<200$ cells ml $^{-1}$ were enumerated in a custom-made $2 \mathrm{ml}$ sedimentation chamber. The growth rate $\left(\mu, \mathrm{d}^{-1}\right)$ of $M$. rubrum was calculated using:

$$
\mu=\ln \left(N_{1}-N_{0}\right) t^{-1}
$$

where $N_{0}$ is the concentration of cells at Time 0 (cells ml-1), $N_{1}$ is the concentration of cells at Time 1 (cells ml ${ }^{-1}$ ) and $t$ is the experimental time (h).

The ingestion rate of Mesodinium rubrum was determined from the reduction in prey concentrations over periods of $5 \mathrm{~d}$ compared to the growth of the control cultures, as described by Jakobsen \& Hansen (1997). The ingestion rate $U$ was estimated using the following 2 equations:

$$
\begin{aligned}
& \frac{\mathrm{d} x}{\mathrm{~d} t}=\mu_{x}-U_{y} \\
& \frac{\mathrm{d} y}{\mathrm{~d} t}=\mu_{y} y
\end{aligned}
$$

where prey $(x)$ is ingested by grazers $(y)$, assuming that grazers grow exponentially with the rate constant of $\mu_{y}$ and that Prey $x$ grows with the rate constant of $\mu_{x}$. The mortality of the cryptophytes due to grazing is $U_{Y}$, where $U$ (cells predator ${ }^{-1} \mathrm{~d}^{-1}$ ) is the per capita ingestion rate, which is independent of $x$. The ingestion rate $(U)$ was iteratively calculated using 'Prey' (by B. Vismann) software (Jakobsen \& Hansen 1997).

Growth and ingestion rate data were fitted to a Michaelis-Menten equation such that:

$$
\mu=\frac{\mu_{\max }\left(x-x_{0}\right)}{K_{m}+\left(x-x_{0}\right)}
$$

where $\mu_{\max }$ is the maximum growth rate $\left(\mathrm{d}^{-1}\right), x$ is the prey concentration $\left(\right.$ cells ml ${ }^{-1}$ ), $x_{0}$ is the threshold prey concentration for growth and $K_{\mathrm{m}}$ is the prey concentration sustaining $1 / 2 \mu_{\max }$ and:

$$
U=\frac{U_{\max }(x)}{K_{m}+x}
$$

where $U_{\max }$ is the maximum ingestion rate (cells predator $\left.{ }^{-1} \mathrm{~d}^{-1}\right), x$ is the prey concentration (cells ml ${ }^{-1}$ ) and $K_{\mathrm{m}}$ is the prey concentration sustaining $1 / 2 U_{\max }$.

Clearance, i.e. the volume of water cleared of prey cells, is:

$$
C=\frac{U_{x}}{X} \times 1000
$$

where $C$ is clearance $\left(\mu l\right.$ cell $\left.^{-1} \mathrm{~d}^{-1}\right), U_{x}$ is the per capita ingestion rate and $x$ is the prey concentration. Clearance data were fitted to the Michaelis-Menten equation.

The contribution of ingested carbon to growth. Linear dimensions of Lugol-fixed cells (both predator and prey) from both light regimes were measured in a Sedgewick-Rafter chamber using an inverted microscope at $400 \times$. These measurements were used to calculate the cell volume for all cells using an approximated geometrical form. For Mesodinium rubrum cells a rotational ellipsoid was used, while for the Teleaulax sp. cells the added volume of a hemisphere and a cone was used. The carbon conversion factor chosen here is 0.19 pg C $\mathrm{\mu m}^{-3}$ (from Putt \& Stoecker 1989), in order to make direct comparisons with the results of Yih et al. (2004) (Table 1).

The carbon contribution of the prey (CCP) was calculated as follows:

$$
\mathrm{CCP}(\%)=\frac{\mathrm{C} \text { cell }_{\text {prey }}^{-1} \times U_{\text {mean }} \times \mathrm{GE}}{C \text { cell }_{\text {pred }}^{-1} \times \mu} \times 100
$$

where CCP is that percentage of the predators' total carbon content for which the ingested prey is responsible, $C$ cell $^{-1}$ prey is the carbon content of Teleaulax sp. (pg cell ${ }^{-1}$ ), $\mathrm{U}_{\text {mean }}\left(\right.$ cells predator ${ }^{-1} \mathrm{~d}^{-1}$ ) is the mean ingestion rate, GE represents predator growth efficiency (0.33; Hansen et al. 1997), $\mathrm{C} \mathrm{cell}^{-1}$ pred is the carbon content of $M$. rubrum and $\mu\left(\mathrm{d}^{-1}\right)$ is the predator growth rate.

\section{RESULTS}

\section{Growth and pH dynamics}

The proliferation of Mesodinium rubrum and Teleaulax sp. was studied in mixed cultures initiated at cell concentrations of $\sim 250$ and $\sim 2000$ cells $\mathrm{ml}^{-1}$, respectively (Fig. 1A). A monoculture of Teleaulax sp. served as control. The control culture grew at a rate of $0.9 \mathrm{~d}^{-1}$ for the first $7 \mathrm{~d}$, resulting in an increase of $\mathrm{pH}$ in the growth media from 7.9 to 8.5. In the mixed cultures Teleaulax sp. were ingested by $M$. rubrum, resulting in

Table 1. Mesodinium rubrum. Starvation response of cumulative growth cultures for 2 irradiances (LL: low light, $20 \mu \mathrm{E} \mathrm{m}^{-2} \mathrm{~s}^{-1}$; HL: high light, $100 \mu \mathrm{E} \mathrm{\textrm {m } ^ { - 2 }}$ $\mathrm{s}^{-1}$ ) and 2 nutritional states (starved and well fed with Teleaulax sp.), see Fig. 2 No-food divisions: number of cell divisions from the onset of starvation before the culture started to die

\begin{tabular}{|lccc|}
\hline & LL starved & HL starved & HL well fed \\
\hline Yield (cells ml $\left.{ }^{-1} \pm \mathrm{SE}\right)$ & $53199 \pm 3727$ & $46342 \pm 8657$ & $382869 \pm 50772$ \\
$\mu$ (initial growth rate) & 0.22 & 0.30 & 0.45 \\
No-food divisions & 4.3 & 3.6 & 3.35 \\
(exponential growth) & & & \\
\hline
\end{tabular}



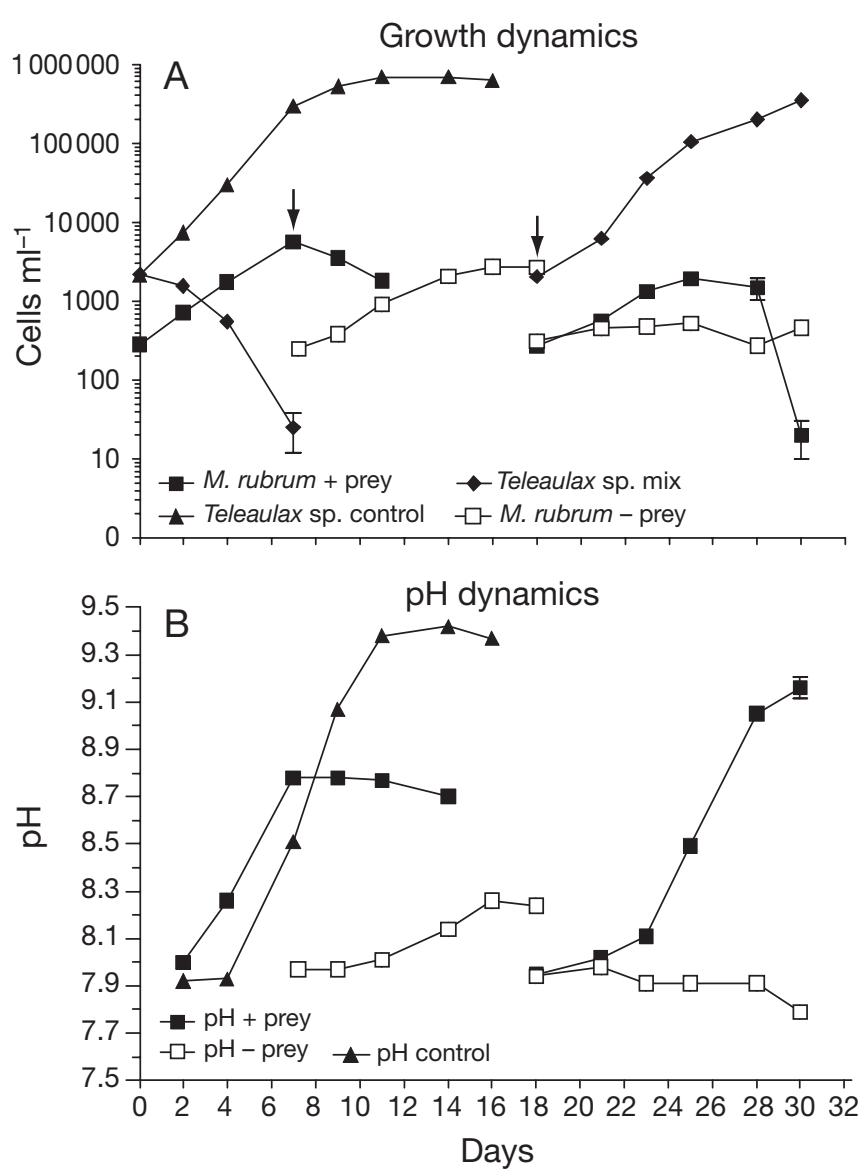

Fig. 1. Mesodinium rubrum. (A) Growth and survival responses of control cultures and mixed cultures of $M$. rubrum and Teleaulax sp. under different prey conditions. (B) $\mathrm{pH}$ monitored during the growth experiments of the control and mixed cultures. Arrows indicate dilution; data points represent means of the triplicates $( \pm \mathrm{SE})$. Where no error bars are shown, the error was smaller than the symbol

depletion of prey on Day 7. In the mixed cultures M. rubrum grew at a rate of $0.45 \mathrm{~d}^{-1}$ for the first $7 \mathrm{~d}$, resulting in a rise of $\mathrm{pH}$ from 8.0 to 8.8. After Day 7 the ciliates in the mixed culture started to die, coinciding with a $\mathrm{pH}$ of $\sim 8.8$. A subculture of the mixed culture was diluted with fresh growth medium to a new initial concentration of 250 cells ml $^{-1}$ on Day 7 (pH 8.0) and was allowed to grow for a further $9 \mathrm{~d}$ with no prey added, resulting in 3 to 4 cell divisions, after which growth stopped. In this period the $\mathrm{pH}$ rose from 8.0 to 8.3 (Day 16), after which pH stagnated. On Day 18 this culture was used to initiate 2 new cultures at $\sim 250$ cells $\mathrm{ml}^{-1}$. One of the cultures was fed Teleaulax sp. (2000 cells $\mathrm{ml}^{-1}$ ) and the other remained unfed. The fed culture resumed growth at a rate of $\sim 0.40 \mathrm{~d}^{-1}$ until Day 25 . In this time span the ciliates were unable to control the number of Teleaulax sp. cells, which in the same period proliferated to $\sim 200000$ cells $\mathrm{ml}^{-1}$, while $\mathrm{pH}$ rose from 7.9 to 8.5. After Day 25, $\mathrm{pH}$ continued to rise, to a value of 9.2 by the termination of the experiment on Day 30. In this period, the ciliates in this culture died, while they stagnated in the experiment with no added prey. No elevation of $\mathrm{pH}$ was observed in the cultures with no added prey from Day 25 to 30.
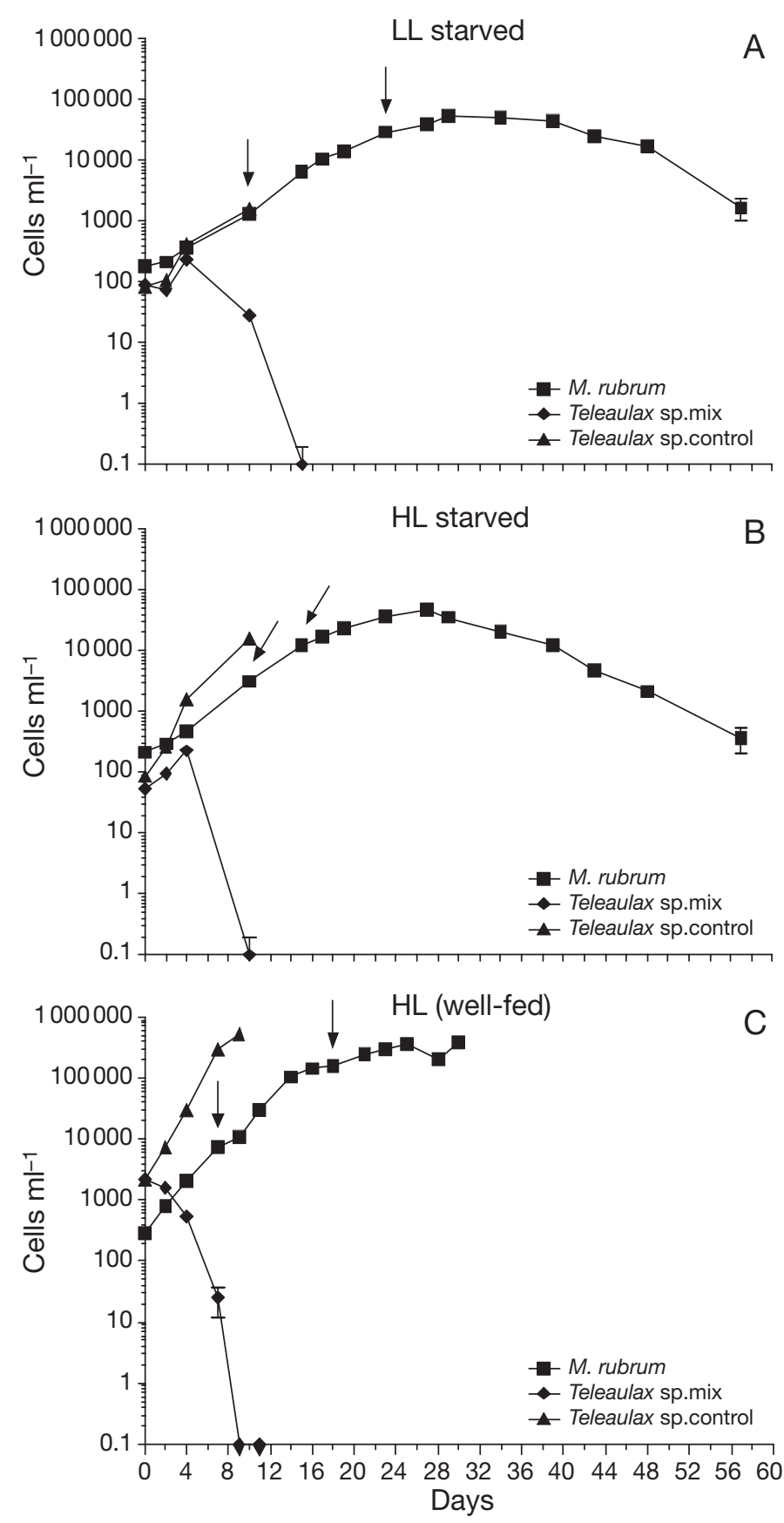

Fig. 2. Mesodinium rubrum. Cumulative growth (correcting for dilutions). (A) Starved $M$. rubrum cells at low light (LL, $20 \mu \mathrm{E} \mathrm{m}^{-2}$ $\mathrm{s}^{-1}$ ). (B) Starved M. rubrum cells at high light (HL, $100 \mu \mathrm{E} \mathrm{m} \mathrm{m}^{-2}$ $\mathrm{s}^{-1}$ ). (C) M. rubrum cells under HL well-fed conditions (growing at their maximum rate). Arrow indicates dilution; data points represent means of the triplicates $( \pm \mathrm{SE})$. Where no error bars are shown, the error was smaller than the symbol 


\section{Impact of starvation}

The starvation response of Mesodinium rubrum was examined in different situations (Fig. 2). In 1 set of experiments ciliates grown at 2 irradiances (20 and $100 \mu \mathrm{mol}$ photons $\mathrm{m}^{-2} \mathrm{~s}^{-1}$, LL and HL, respectively) were acclimated to low prey concentrations (starved) before each experiment was initiated. In another set of experiments, ciliates grown at high irradiance and with plenty of food were allowed to graze down their prey and then subsequently subjected to starvation. To avoid $\mathrm{pH}$ effects, cultures were diluted before they reached a $\mathrm{pH}$ that could affect their growth ( $\mathrm{pH}$ always <8.5). Data are shown as cumulative growth to facilitate comparisons.

A monoculture of Teleaulax sp. served as a control in all 3 experiments. The Teleaulax sp. monoculture proliferated to a concentration in excess of 100000 cells $\mathrm{ml}^{-1}$ in all cases (not all data are shown). Prey concentrations in the 2 starvation experiments were $\sim 100$ and 2000 cells $\mathrm{ml}^{-1}$ for the well-fed treatments. Ingestion rates were $\sim 0.15$ cells predator ${ }^{-1} \mathrm{~d}^{-1}$ at Day 7 in all cases (Fig. 3), as a function of approximately the same prey concentration. The Mesodinium rubrum of the LL culture grew slowly, at a rate of $0.22 \mathrm{~d}^{-1}$ from Day 7 to 33 (Table 1). At Day 29 the culture reached its maximum cell yield of $\sim 50000$ cells $\mathrm{ml}^{-1}$ (Table 1 ). The growth rate showed no response to starvation until Day 23, when the culture slowly declined until extinction after $50 \mathrm{~d}$. The starved HL culture grew at a rate of $0.30 \mathrm{~d}^{-1}$ from Day 7 to 15 (Table 1). This culture

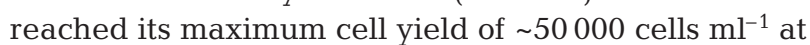
Day 27 (Table 1). The well-fed culture grew at a rate of $0.45 \mathrm{~d}^{-1}$ from Day 7 to 14 , after which it exhibited a growth rate comparable to the starved HL culture, until the maximum cell yield of $\sim 400000$ cells ml ${ }^{-1}$ was reached on Day 25. All cultures were able to divide 3 to 4 times from Day 7 (no prey) to the day of their maximum cell yield (Table 1).

\section{Functional and numerical response}

Maximum growth rates of Mesodinium rubrum at prey saturation were 0.23 and $0.49 \mathrm{~d}^{-1}$, at irradiances of 20 and $100 \mu \mathrm{mol}$ photons $\mathrm{m}^{-2} \mathrm{~s}^{-1}$ (LL and HL), respectively. A reduction in growth rate at both irradiances was observed at prey concentrations $<1000$ Teleaulax sp. cells $\mathrm{ml}^{-1}$. However, prey concentrations as low as $\sim 50$ cells $\mathrm{ml}^{-1}$ were sufficient for positive growth of $M$. rubrum at both irradiances (Fig. 4A).

Ingestion rate as a function of prey concentration could be closely fitted to Michaelis-Menten kinetics. The maximum ingestion rates of Mesodinium rubrum were not significantly different between the 2 selected irradiances, and estimated maximum rates were $\sim 6$ prey ciliate $\mathrm{d}^{-1}(\mathrm{p}<0.01)$. Ingestion rates of $\sim 1$ prey $\mathrm{d}^{-1}$ were sufficient to maintain maximum growth rate (Fig. 4A,B).

The data on growth and ingestion rates makes it possible to compare actual growth rate with the potential growth that can be estimated using the ingestion rate and assuming a growth yield of $33 \%$. The calculated data show that $\sim 22$ and $15 \%$ of the observed growth of Mesodinium rubrum potentially could be derived from food uptake at 20 and $100 \mu \mathrm{mol}$ photons $\mathrm{m}^{-2} \mathrm{~s}^{-1}$, respectively, at high prey concentrations. At lower prey concentrations, the contribution of ingested carbon to the growth of $M$. rubrum decreased at both irradiances, and, at prey concentrations $<1000$ cells $\mathrm{ml}^{-1}$, the contribution of food uptake at the 2 irradiances was quite small and not significantly different (Fig. 4C, Table 2).

A comparison of the maximum clearance at the 2 irradiances reveals that they were not significantly different from each other ( $p>0.01$, Fig. 5). Hence, the clearance decreased from $\sim 1.1 \mu$ cells $\mathrm{d}^{-1}$ at low prey concentration to $\sim 0.5 \mu \mathrm{l}$ cells $\mathrm{d}^{-1}$ at very high prey concentrations when the 2 graphs were combined.
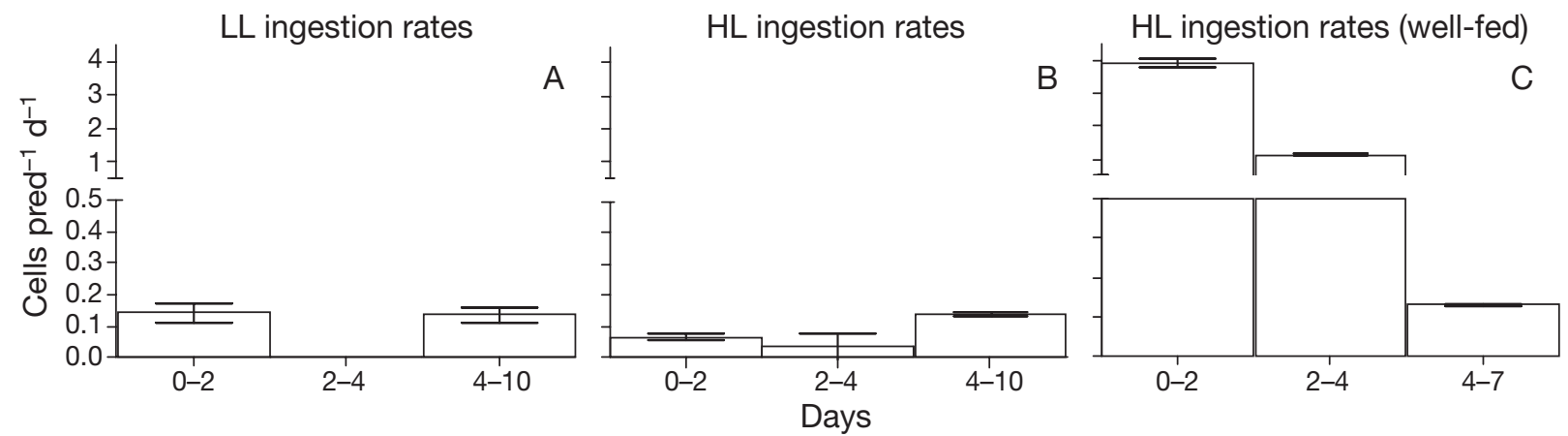

Fig. 3. Mesodinium rubrum. Ingestion rates in the starvation experiments (see Fig 2). (A) Starved M. rubrum cells at low light (LL). (B) Starved M. rubrum cells at high light (HL). (C) M. rubrum cells under HL well-fed conditions (growing at their maximum rate). Data points represent means of the triplicates $( \pm \mathrm{SE})$. pred: predator. For details of LL and HL see Fig. 2 

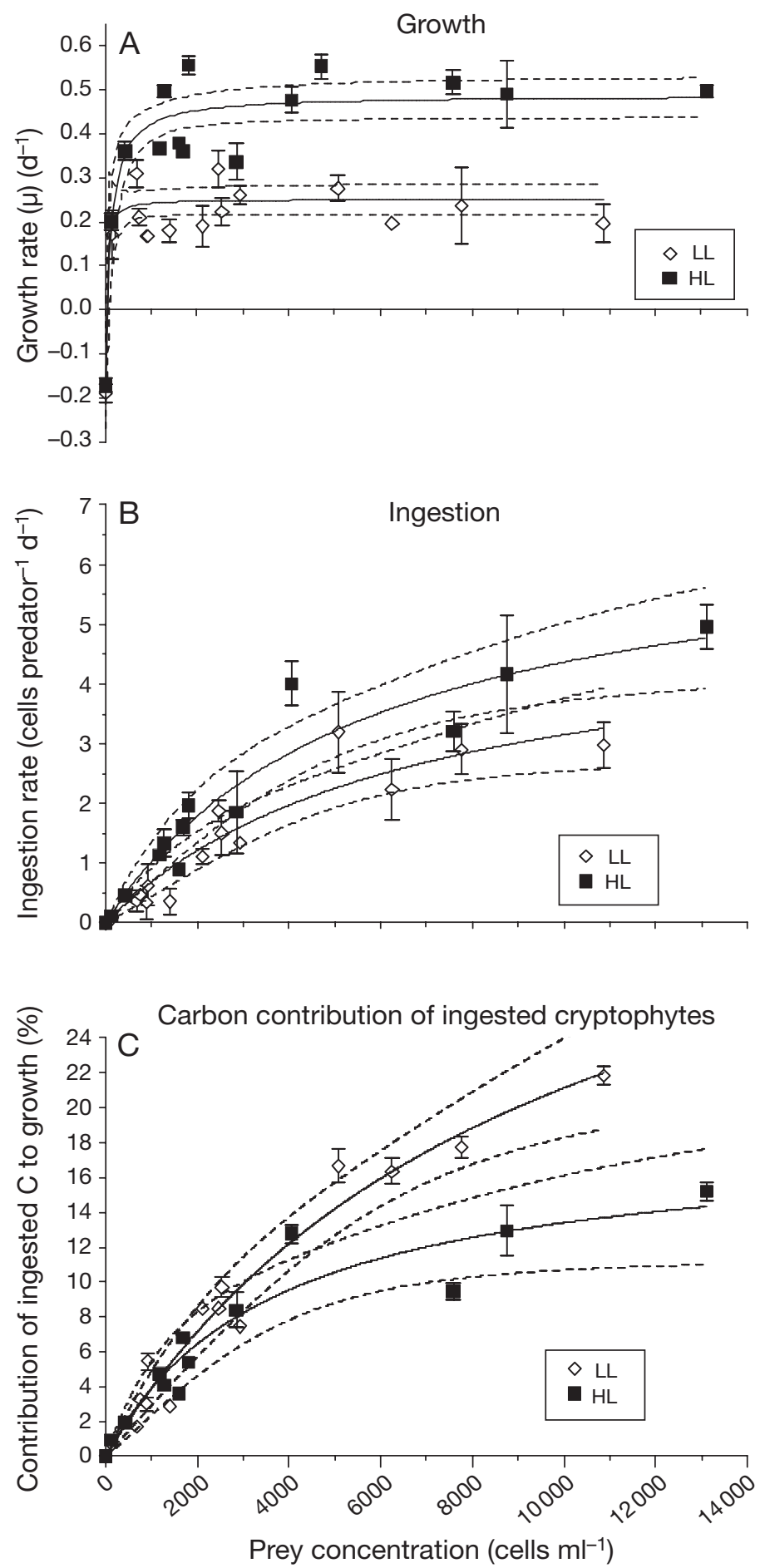

Fig. 4. Mesodinium rubrum. (A) Growth of M. rubrum under 2 irradiances as a function of prey (Teleaulax sp.) concentration. (B) Ingestion rate of Teleaulax sp. cells as a function of prey concentration (no difference between curves, $p>0.05$ ). (C) Contribution of ingested prey carbon to growth (for cell volume to carbon content conversions, see Table 2), assuming $33 \%$ growth efficiency as a function of prey concentration. All data points are means of triplicates $( \pm \mathrm{SE})$. Broken lines denote $99 \%$ confidence intervals. LL: low light; HL: high light. Where no error bars are shown, the error was smaller than the symbol
Table 2. Mesodinium rubrum, Teleaulax sp. Cell volume converted to carbon content. No significant difference was observed between irradiances $(p>0.05)$. LL: low light; HL: high light

\begin{tabular}{|lcc|}
\hline & $\begin{array}{c}\text { Cell volume } \\
\left(\mu \mathrm{m}^{-3}, \pm \mathrm{SE}\right)\end{array}$ & $\begin{array}{r}\text { Carbon content } \\
\left.\text { (pg C cell }^{-1}, \pm \mathrm{SE}\right)\end{array}$ \\
\hline M. rubrum (LL) & $3467 \pm 460$ & $661 \pm 87$ \\
M. rubrum (HL) & $4284 \pm 315$ & $833 \pm 60$ \\
Teleaulax sp. (LL) & $131 \pm 8$ & $29 \pm 2$ \\
Teleaulax sp. (HL) & $175 \pm 26$ & $38 \pm 6$ \\
\hline
\end{tabular}

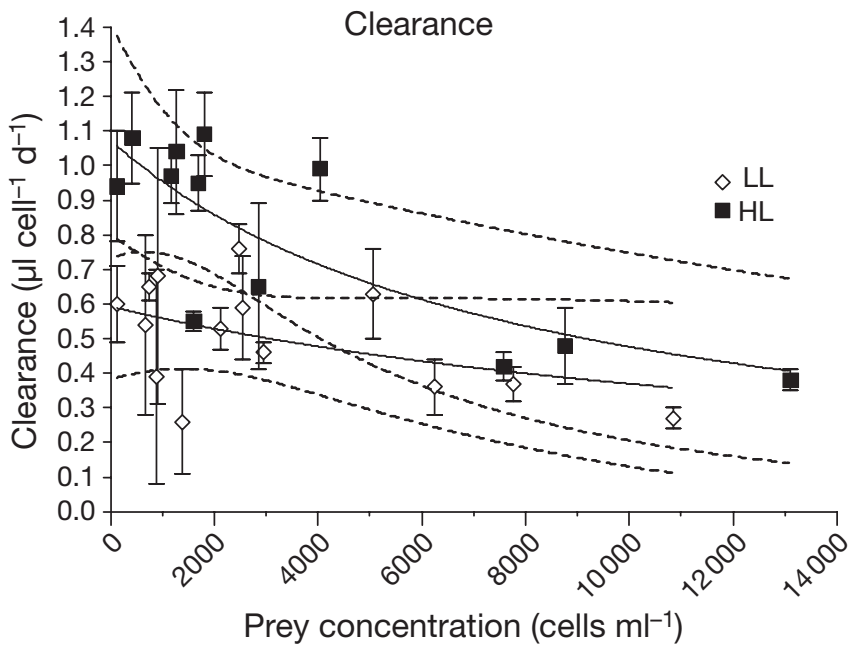

Fig. 5. Mesodinium rubrum. Clearance of $M$. rubrum as a function of prey (Teleaulax sp.) concentration (no difference between curves, $\mathrm{p}>$ 0.01). Broken lines denote $99 \%$ confidence intervals. LL: low light; HL: high light

\section{DISCUSSION}

\section{Growth and pH dynamics}

The prey of Mesodinium rubrum, Teleaulax sp., is fairly tolerant to high $\mathrm{pH}$. Its growth is affected when $\mathrm{pH}$ exceeds 8.8, but it maintains a positive growth rate until a $\mathrm{pH}$ value of 9.4 is reached. This behaviour is far more tolerant than that of the $M$. rubrum isolate we used, which stops growing at $\mathrm{pH} 8.8-\mathrm{a}$ value similar to the $\mathrm{pH}$ limit observed for another $M$. rubrum clone (Hansen \& Fenchel 2006). A consequence of this poor tolerance to high $\mathrm{pH}$ is that great care must be taken to always allow the predator to be able to control the prey and to dilute the cultures before $M$. rubrum reaches the critical concentration (Fig. 1). This can be achieved if the concentration of M. rubrum is kept under 5000 to 6000 cells $\mathrm{ml}^{-1}$, which corresponds to a $\mathrm{pH}$ of 8.8 (Fig. 1). Thus, when working with mixed cultures of $M$. rubrum and its prey, it is essential to find a window of opportunity where growth for both organisms is not depressed by high $\mathrm{pH}$. 
Why exactly high $\mathrm{pH}$ impedes growth of photoautotrophs is at present pure speculation, but there are several hypotheses (e.g. Lundholm et al. 2004). High $\mathrm{pH}$ will shift the speciation of inorganic carbon. At a $\mathrm{pH}$ of 8.0 , only $1 \%$ of the total dissolved inorganic carbon is available as $\mathrm{CO}_{2}$; at a $\mathrm{pH}$ of 9.0 , it is $0.1 \%$ (Hinga 2002). So in order to keep photosynthesis going, phototrophs need to use another carbon source, i.e. $\mathrm{HCO}_{3}{ }^{-}$ (bicarbonate) (Giordano et al. 2005). Unlike $\mathrm{CO}_{2}$, bicarbonate cannot diffuse freely across the plasma membrane; any use of bicarbonate is therefore dependent upon a carbon-concentrating mechanism (CCM) and the enzyme carbonic anhydrase (CA), which facilitates the actual conversion to RUBISCO's substrate $\mathrm{CO}_{2}$ (Giordano et al. 2005).

Alternatively, it is possible that high extracellular $\mathrm{pH}$ may affect intracellular $\mathrm{pH}$ and thereby have an impact, for example, on intracellular enzyme function or ion transport (Lundholm et al. 2004, Giordano et al. 2005).

In the present case, one may wonder why Mesodinium rubrum is more sensitive to high $\mathrm{pH}$ than Teleaulax sp. The endosymbiont of $M$. rubrum is presumably quite closely related to Teleaulax sp., and, if so, they may share the ability to tolerate high $\mathrm{pH}$ values. Thus, the ciliate should, in principle, be just as tolerant to high $\mathrm{pH}$ as Teleaulax sp. However, a number of issues have to be taken into account, like the intracellular $\mathrm{pH}$ of $M$. rubrum, the $\mathrm{pH}$ tolerance of $M$. rubrum itself and the CCM of $M$. rubrum.

Nothing is known about the intracellular $\mathrm{pH}$ of Mesodinium rubrum; thus, nothing is known about the environment in which the chloroplasts live. Whether cryptophytes have a CCM and CA available to their photosynthetic apparatus is at present undocumented. It would, however, be very surprising if this were not the case, as Teleaulax sp. grows at a $\mathrm{pH}$ in excess of 9.2 where the water is almost completely devoid of $\mathrm{CO}_{2}$.

It is, however, known that the tolerance to high $\mathrm{pH}$ varies among heterotrophic ciliates. Some ciliates cannot grow when $\mathrm{pH}$ exceeds 8.8, just like Mesodinium rubrum, while others can grow at their maximum rate at $\mathrm{pH}$ values exceeding 9.2 and can maintain growth at values as high as 9.8 (Pedersen \& Hansen 2003a,b). Thus, the lack of tolerance of $M$. rubrum to high $\mathrm{pH}$ may reflect the lack of $\mathrm{pH}$ tolerance of the ciliate. It is also a possibility that $M$. rubrum, as it is a ciliate, lacks a CCM, but, on the other hand, it is also possible that a CCM could be encoded by the symbiont or by a transfer of cryptophyte genes to the ciliate. This is very common among protists (e.g. Watanabe et al. 1990). So the growth depression and, ultimately, the death of M. rubrum could also be due to a depletion of bioavailable inorganic carbon.

\section{Functional and numerical response}

The present Mesodinium rubrum isolate is indeed a

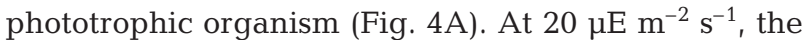
growth rate is about half that at $100 \mu \mathrm{E} \mathrm{m} \mathrm{m}^{-2} \mathrm{~s}^{-1}$. This response is in accordance with the findings of other studies for other phototrophic (in the widest possible sense) protists (e.g. Skovgaard 1996, Jakobsen et al. 2000). The growth rate of $M$. rubrum is, however, not solely dependent upon irradiance. $M$. rubrum needs to ingest $\sim 0.05$ Teleaulax sp. cells $\mathrm{d}^{-1}$ for positive growth, irrespective of irradiance (Fig. 4B). In fact, the irradiances chosen for these experiments do not seem to affect the ingestion rates at all (Fig. 4B). The growth rate is, however, not augmented beyond an ingestion rate of approximately 1 Teleaulax sp. cell $\mathrm{d}^{-1}$. The data of Yih et al. (2004) suggest an even lower ingestion rate $\left(0.2\right.$ to 0.4 cells $\left.\mathrm{d}^{-1}\right)$ for maximum growth. This could, however, just be due to the fact that they evaluated fewer data points than those considered in this study. Furthermore, the results of Yih et al. (2004) were also affected by an acclimation period that was too short. Yih et al. (2004) did not observe the death of $M$. rubrum in prey-depleted cultures, which is clearly a result of the insufficient acclimation period.

Heterotrophic and mixotrophic ciliates of a comparable size, e.g. Balanion comatum, Laboea strobila and Tiarina fusus, generally need to ingest 10 to 50 times more prey than Mesodinium rubrum to maintain maximum growth rates (Stoecker et al. 1988, Jakobsen \& Hansen 1997, Jeong et al. 2002). Calculations of the contribution of food uptake to the overall growth of $M$. rubrum reveal that food uptake only explains between 2 and $4 \%$ of the carbon required for the maximum growth rate. Under LL conditions $M$. rubrum is able to increase the contribution from food uptake to $22 \%$, but this increased ingestion does not correspond to an increase in growth. Under HL conditions this increase is significantly lower $(15 \%)$ ( $p<$ 0.01) (Fig. 4C). This rather peculiar functional/numerical response has not been observed in strict heterotrophs (e.g. Jakobsen \& Hansen 1997), such as the ciliate Balanion comatum and the dinoflagellate Gymnodinium sp., when they were fed Rhodomonas salina. Other precedent studies on mixotrophs do, however, report mismatch between food uptake and growth, as well as between photosynthesis and growth (e.g. Jakobsen et al. 2000), although this 'overfeeding' response is not fully understood. We hypothesise that $M$. rubrum changes 'strategy' and down-regulates its photosynthetic apparatus when offered food in excess. This has been observed for some facultative mixotrophic dinoflagellates that are able to survive in darkness, e.g. Fragilidium subglo- 
bosum (Skovgaard 1996). The heterotrophic contribution to the growth of $M$. rubrum in this study exceeds the values determined by Yih et al. (2004) (Table 3), which could be due to the lower ingestion rates reported there.

If Mesodinium rubrum do not supplement photosynthesis with carbon through food uptake, why indeed do they eat? In the case of the freshwater chrysophyte Uroglena americana, bacteria are ingested, and a bacterial phospholipid has been identified as obligate for growth (e.g. Kimura \& Ishida 1989). No chemical compound has been identified as a growth factor for mixotrophic freshwater cryptophytes, but the uptake of bacteria has been documented (Pålsson \& Granéli 2003). Not much work has been done in this area on marine cryptophytes, but it would be rather unexpected if marine species were to differ in this respect.

The symbiont of Mesodinium rubrum is embedded in the ciliate, so ingestion of bacterivorous cryptophytes could be a way of supplying necessary growth factors that the symbiont itself is unable to obtain (Havskum \& Riemann 1996). The involvement of growth factors has also been reported in numerous publications on mixotrophy of non-bacterial prey (e.g. Skovgaard 2000).

The present data support the existence of a growth factor, which is diluted through cell divisions. The LL and HL starved cultures are able to divide 3 to 4 times from the onset of prey depletion to maximum cell yield, regardless of the irradiance (Table 1). The same number of divisions has been observed for an Antarctic isolate, though the growth rate in this case is about half as high as that of the isolate we used (Johnson \& Stoecker 2005). The low growth rate is mainly due to the low temperature in which these cultures were kept $\left(2^{\circ} \mathrm{C}\right)$. Furthermore, the LL cultures (starved) grow at half the rate of the HL well-fed cultures, but they do so for $15 \mathrm{~d}$ as opposed to the $7 \mathrm{~d}$ of the HL well-fed culture (Fig. 2A,C). Thus, the nutritional prehistory of the cultures apparently does not influence the number of divisions made from the onset of prey depletion to the maximum cell yield (Table 1). The conclusion that can be drawn from this is that $M$. rubrum is unable to store the growth factor obtained in times of feast for use in times of famine.

Table 3. Mesodinium rubrum cultured on Teleaulax spp. Comparison of studies

\begin{tabular}{|lccc|}
\hline Sampling site & $\begin{array}{c}\text { Ingestion rate } \\
\text { (cells predator } \mathrm{d}^{-1} \text { ) }\end{array}$ & $\begin{array}{c}\text { Contribution of ingested } \\
\text { C to growth (\%) }\end{array}$ & Source \\
\hline $\begin{array}{c}\text { Gomso Bay, } \\
\text { South Korea } \\
\begin{array}{c}\text { Ellsinore Harbour, } \\
\text { Denmark }\end{array}\end{array}$ & $0.2-2.8$ & $0.06-5.5$ & Yih et al. (2004) \\
\hline
\end{tabular}

\section{Ecological adaptations of Mesodinium rubrum}

The seasonal abundance of $M$. rubrum in coastal waters is well established. The reports are somewhat contradictory on whether or not $M$. rubrum follows the spring bloom of the phytoplankton, but they do agree that $M$. rubrum is present at low concentrations in summer. An increase in early autumn is commonly found, and M. rubrum cells are even found in reasonable numbers during winter. Although the data in these papers are not complete, a yearly mean concentration of approximately $1 \mathrm{M}$. rubrum $\mathrm{ml}^{-1}$ has been reported (Montagnes \& Lynn 1989, Nielsen \& Kiørboe 1994, Sanders 1995).

In coastal marine waters $\mathrm{pH}$ values in excess of 9.0 are often found in summer (e.g. Macedo et al. 2001 Hansen 2002). This could have an effect on the propagation of Mesodinium rubrum. Mesocosm incubations show that the growth of M. rubrum is negatively affected at a pH >8.5 (Pedersen \& Hansen 2003a); this could easily be the case in nature as well, but has not yet been documented.

Knowledge on the availability of suitable prey for Mesodinium rubrum is very limited, but up to now $M$. rubrum has only been successfully cultured using Teleaulax spp. as prey. No studies have been published in which $M$. rubrum and Teleaulax spp. were quantified for an entire year. The 1 study that exists in which Teleaulax sp. was quantified for a year reports concentrations of Teleaulax sp. of about 20 to 100 cells $\mathrm{ml}^{-1}$ (Hill et al. 1992). The material used in the present study originates from Danish waters, but this genus has been isolated off Antarctica and Korea as well. If the Teleaulax sp. concentrations reported in Hill et al. (1992) can be applied to coastal waters around the world, then $M$. rubrum only rarely encounters prey concentrations in excess of the 1000 Teleaulax spp. cells $\mathrm{ml}^{-1}$ that, according to the present study, are needed to maintain maximum growth rates.

Cryptophytes are, however, food of high quality and are, therefore, often a preferred food among protists and metazoans (e.g. Meyer-Harms \& von Bodungen 1997, Jakobsen et al. 2000, Tang et al. 2001). The competition for this food source, combined with the fact that Mesodinium rubrum needs a concentration of 50 Teleaulax sp. cells $\mathrm{ml}^{-1}$ to maintain positive growth rates, could easily mean that M. rubrum's food source is limited due to grazing by other species. During bloom formation it may even exhaust its own food source. Calculations based on clearance rates and the approximated concentrations of $M$. rubrum and its prey Teleaulax sp. predict that $M$. 
rubrum's potential clearance is 1 to $11 \%$ of the Teleaulax spp. population per day at a concentration of $1 \mathrm{M}$. rubrum $\mathrm{ml}^{-1}$. If the concentration of $M$. rubrum soars, it could have a significant impact on the Teleaulax spp. population. At present, however, no experimental data exist confirming that $M$. rubrum can survive on a diet of other cryptophyte genera or even other flagellates such as prymnesiophytes and prasinophytes.

Mesodinium rubrum commonly blooms in coastal waters and thus may experience extended periods with no or almost no food available (Taylor et al. 1971, Hill et al. 1992, Nielsen \& Kiørboe 1994). One important discovery in the present study was that $M$. rubrum is well adapted to periods without food. Even after 1 to 2 wk without food, M. rubrum easily resumes growth when prey become available again. In this respect, $M$. rubrum differs from most other planktonic protists that exploit cryptophytes. Some species, like the strictly heterotrophic ciliate Balanion comatum, the bacterivorous ciliate Euplotes patella and the chloroplast-retaining ciliate Laboea strobila, can only survive for about 2 d in food-depleted cultures (Jackson \& Berger 1984, Stoecker et al. 1988, Jakobsen \& Hansen 1997). Thus, it seems clear that $M$. rubrum is much better adapted to survive in heterogeneous environments, with respect to prey concentration. This ability to avoid starvation may also explain why $M$. rubrum is present in most coastal waters year round, while the seasonal distribution of other planktonic protistan grazers is more periodic (Nielsen \& Kiørboe 1994).

Acknowledgements. The work was funded by the Danish Natural Research Council Project No. 21-03-0449 to P.J.H.

\section{LITERATURE CITED}

Giordano M, Beardall J, Raven JA (2005) $\mathrm{CO}_{2}$ concentrating mechanisms in algae: mechanisms, environmental modulation and evolution. Annu Rev Plant Biol 56:99-131

Guillard RRL (1983) Culture of phytoplankton for feeding invertebrate animals. In: Berg CJ (ed) Culture of marine invertebrates. Hutchinson Ross, Stroudsberg, PA, p 123-128

Gustafson DE, Stoecker DK, Johnson MD, van Heukelem WF, Sneider K (2000) Cryptophyte algae robbed of their organelles by the marine ciliate Mesodinium rubrum. Nature 405:1049-1052

Hansen PJ (2002) Effect of high pH on the growth and survival of marine phytoplankton: implications for species succession. Aquat Microb Ecol 28:279-288

Hansen PJ, Fenchel T (2006) The bloom-forming ciliate Mesodinium rubrum harbours a single permanent endosymbiont. Mar Biol Res 2:169-177

Hansen PJ, Hansen B, Bjørnsen PK (1997) Zooplankton grazing and growth: scaling within the size range $2 \mathrm{~mm}$ to 2000 mm. Limnol Oceanogr 42(4):687-704

Havskum H, Riemann B (1996) Ecological importance of bactivorous, pigmented flagellates (mixotrophs) in the Bay of Aarhus, Denmark. Mar Ecol Prog Ser 137:251-263
Hibberd DJ (1977) Ultrastructure of the cryptomonad endosymbiont of the red-water ciliate Mesodinium rubrum. J Mar Biol Assoc UK 57:45-61

Hill DR, Moestrup Ø, Vørs N (1992) Plankton i de indre danske farvande, Vol 11. Danish Environmental Protection Agency, Danish Ministry of the Environment, Copenhagen

Hinga KR (2002) Effects of $\mathrm{pH}$ on a coastal marine phytoplankton. Mar Ecol Prog Ser 238:281-300

Jackson KM, Berger J (1984) Survival of ciliate protozoa under starvation conditions and at low bacterial levels. Microb Ecol 10:47-59

Jakobsen HH, Hansen PJ (1997) Prey size selection, grazing and growth response of the small heterotrophic dinoflagellate Gymnodinium sp. and the ciliate Balanion comatum - a comparative study. Mar Ecol Prog Ser 158: 75-86

Jakobsen HH, Hansen PJ, Larsen J (2000) Growth and grazing responses of two chloroplast-retaining dinoflagellates: effect of irradiance and prey species. Mar Ecol Prog Ser 201:121-128

Jakobsen HH, Everett LM, Strom SL (2006) Hydromechanical signaling between the ciliate Mesodinium pulex and motile protist prey. Aquat Microb Ecol 44:197-206

Jeong HJ, Yoon JY, Kim JS, Yoo YD, Seong KA (2002) Growth and grazing rates of the prostomatid ciliate Tiarina fusus on red tide and toxic algae. Aquat Microb Ecol 28:289-297

Johnson MD, Stoecker DK (2005) Role of feeding in growth and photophysiology of Myrionecta rubra. Aquat Microb Ecol 39:303-312

Kimura B, Ishida Y (1989) Phospholipid as a growth factor of Uroglena americana, a red tide Chrysophyceae in Lake Biwa. Nippon Suisan Gakkaishi 55:799-804

Kudo RR (1954) Protozoology, 4th edn. Thomas Books, Springfield, IL

Lindholm T (1985) Mesodinium rubrum - a unique photosynthetic ciliate. Adv Aquat Microb 8:1-48

Lindholm T, Lindroos P, Mørk A (1988) Ultrastructure of the photosynthetic ciliate Mesodinium rubrum. BioSystems 21:141-149

Lohmann H (1908) Untersuchungen zur Feststellung des vollständigen Gehaltes des Meeres an Plankton. Wiss Meeresunters 10:129-370

Lundholm N, Hansen PJ, Kotaki Y (2004) Effect of pH on growth and domoic acid production by potentially toxic diatoms of the genera Pseudo-nitzschia and Nitzschia. Mar Ecol Prog Ser 273:1-15

Macedo MF, Duarte P, Mendes P, Ferreira JG (2001) Annual variation of environmental variables phytoplankton species composition and photosynthetic parameters in a coastal lagoon. J Plankton Res 23(7):719-732

Meyer-Harms B, von Bodungen B (1997) Taxon-specific ingestion rates of natural phytoplankton by calanoid copepods in an estuarine environment (Pomeranian Bight, Baltic Sea) determined by cell counts and HPLC analyses of marker pigments. Mar Ecol Prog Ser 153:181-190

Montagnes DJS, Lynn DH (1989) The annual cycle of Mesodinium in the waters surrounding the Isle of Shoals, Gulf of Maine. J Plankton Res 8:317-327

Nielsen TG, Kiørboe T (1994) Regulation of zooplankton biomass and production in a temperate, coastal ecosystem. 2. Ciliates. Limnol Oceanogr 39(3):508-519

Oakley BR, Taylor FJR (1978) Evidence of a new type of endosymbiotic organization in the population of the ciliate Mesodinium rubrum from British Columbia. BioSystems 10:361-369 
Pålsson C, Granéli W (2003) Diurnal and seasonal variations in grazing by bactivorous mixotrophs in an oligotrophic clearwater lake. Arch Hydrobiol 157(3):289-307

Pedersen MF, Hansen PJ (2003a) Effects of high pH on a natural marine planktonic community. Mar Ecol Prog Ser 260: 19-31

Pedersen MF, Hansen PJ (2003b) Effects of high pH on the growth and survival of six marine heterotrophic protists. Mar Ecol Prog Ser 260:33-41

Putt M, Stoecker DK (1989) An experimentally determined carbon: volume ratio for marine "oligotrich" ciliates estuarine and coastal waters. Limnol Oceanogr 43(6): 1097-1103

Sanders RW (1995) Seasonal distributions of the photosynthesizing ciliates Laboea strobila and Myrionecta rubra (=Mesodinium rubrum) in an estuary of the Gulf of Maine. Aquat Microb Ecol 9:237-242

Skovgaard A (1996) Mixotrophy in Fragilidium subglobosum (Dinophyceae): growth and grazing responses as functions of light intensity. Mar Ecol Prog Ser 143:247-253

Skovgaard A (2000) A phagotrophically derivable growth factor in the plastidic dinoflagellate Gyrodinium resplendens (Dinophyceae). J Phycol 36:1069-1078

Stoecker DK, Michaels AE, Davis LH (1987) Large proportion

Editorial responsibility: Howard Browman (Associate Editorin-Chief), Storebø, Norway of marine planktonic ciliates found to contain functional chloroplasts. Nature 326:790-792

Stoecker DK, Silver MW, Michaels AE, Davis LH (1988) Obligate mixotrophy in Laboea strobila, a ciliate which retains chloroplasts. Mar Biol 99:415-423

Stoecker DK, Putt M, Davis LH, Michaels AE (1991) Photosynthesis in Mesodinium rubrum: species-specific measurements and comparison to community rates. Mar Ecol Prog Ser 73:245-252

Tang KW, Jakobsen HH, Visser AW (2001) Phaeocystis globosa (Prymnesiophyceae) and the planktonic food web: feeding, growth and trophic interactions among grazers. Limnol Oceanogr 46(8):1860-1870

Taylor FJR, Blackbourn DJ, Blackbourn J (1971) The redwater ciliate Mesodinium rubrum and its 'incomplete symbionts': a review including new ultrastructural observations. J Fish Res Board Can 28:391-407

Watanabe MM, Suda S, Inouye I, Sawaguchi T, Chihara M (1990) Lepidodinium viride gen. et sp. nov. (Gymnodiniales, Dinophyta). A green dinoflagellate with a chlorophyll $A-$ and $B$-containing endosymbiont. J Phycol 26:741-751

Yih W, Kim HS, Jeong HJ, Myung G, Kim YG (2004) Ingestion of cryptophyte cells by the marine photosynthetic ciliate Mesodinium rubrum. Aquat Microb Ecol 36:165-170

Submitted: August 25, 2006; Accepted: November 30, 2006 Proofs received from author(s): May 14, 2007 